\title{
Widespread reforestation before European influence on Amazonia
}

Article

Accepted Version

Bush, M. B., Nascimento, M. N., Akesson, C. M., CardenesSandi, G. M., Maezumi, S. Y., Behling, H., Correa-Metrio, A., Church, W., Huisman, S. N., Kelly, T., Mayle, F. E. ORCID: https://orcid.org/0000-0001-9208-0519 and McMichael, C. N. H. (2021) Widespread reforestation before European influence on Amazonia. Science, 372 (6541). pp. 484-487. ISSN 10959203 doi: https://doi.org/10.1126/science.abf3870 Available at https://centaur.reading.ac.uk/97776/

It is advisable to refer to the publisher's version if you intend to cite from the work. See Guidance on citing.

To link to this article DOI: http://dx.doi.org/10.1126/science.abf3870

Publisher: American Association for the Advancement of Science

All outputs in CentAUR are protected by Intellectual Property Rights law, including copyright law. Copyright and IPR is retained by the creators or other copyright holders. Terms and conditions for use of this material are defined in the End User Agreement. 


\section{CentAUR}

Central Archive at the University of Reading

Reading's research outputs online 


\section{Title: Widespread reforestation before European influence on Amazonia}

Authors: M.B. Bush ${ }^{1 *}$, M.N. Nascimento ${ }^{1,3}$, C.M. Åkesson ${ }^{1}$ †, G.M. Cárdenes-Sandí ${ }^{2}$, S.Y. Maezumi ${ }^{3}$, H. Behling $^{4}$, A. Correa-Metrio ${ }^{5}$, W. Church ${ }^{6}$, S.N. Huisman ${ }^{3}$, T. Kelly ${ }^{7}$, F.E. Mayle ${ }^{8}$, C.N.H. McMichael ${ }^{*}$

\section{Affiliations:}

${ }^{1}$ Institute for Global Ecology, Florida Institute of Technology, Melbourne, Florida, USA.

†St. Andrews University, St. Andrews, UK

${ }^{2}$ Escuela Centroamericana de Geología, University of Costa Rica, San José, Costa Rica.

${ }^{3}$ Department of Ecosystem and Landscape Dynamics, Institute for Biodiversity and Ecosystem Dynamics, University of Amsterdam, 904 Science Park, 1098 XH, Amsterdam, Netherlands.

${ }^{4}$ Department of Palynology and Climate Dynamics, University of Goettingen, Goettingen, Germany.

${ }^{5}$ Instituto de Geología, Universidad Nacional Autónoma de México, Ciudad de México 04520, México.

${ }^{6}$ Department of Earth and Space Sciences, Columbus State University, Columbus, Georgia, USA.

${ }^{7}$ School of Geography, Queen Mary University of London, Mile End, London, UK.

${ }^{8}$ Department of Geography \& Environmental Science, University of Reading, Whiteknights, Reading,

15 Berkshire, UK.

*Correspondence to: mbush@fit.edu, c.n.h.momichael@uva.nl

\section{Abstract:}

An estimated $90-95 \%$ of indigenous people in Amazonia died following European Contact. This population collapse is postulated to have caused decreases in atmospheric $\mathrm{CO}_{2}$ concentrations at c. $1610 \mathrm{CE}$, as a result of a wave of land abandonment in the wake of disease, slavery and warfare, whereby the attendant reversion to forest significantly increased terrestrial carbon sequestration. Based on 39 Amazonian fossil pollen records, we show that there was no synchronous reforestation event associated with such an atmospheric $\mathrm{CO}_{2}$ response following European arrival in Amazonia. Instead, we find that, at most sites, land abandonment and forest regrowth began c. 300 - 600 years before European arrival. Pre-European pandemics, social strife or environmental change may have contributed to these early site abandonments and ecological shifts. 


\section{One Sentence Summary: Pollen records show that site abandonment and forest regrowth in Amazonia began up to 600 years before European arrival.}

Main Text: The scale and the spatial and temporal patterns of human population dynamics in Amazonia have long been controversial. Early models suggest an exponential increase that perhaps continued until European contact (1), but more recent assessments suggest that population growth was slowing by c. 1200 CE (hereafter all ages are expressed as CE) (2), perhaps nearing a carrying capacity. After 1492, an estimated $90-95 \%$ of the indigenous population was lost as waves of disease, including smallpox, influenza, measles, and the common cold, swept through 'virgin soil' communities, as well as by warfare and slavery (3). This catastrophic loss of life resulting from European colonization has been termed the 'Great Dying of the Indigenous Peoples of the Americas' (4). The population collapse is commonly considered a turning point in human influence on Amazonian landscapes, as inhabited sites were abandoned and land used for crop cultivation became fallowed (Fig. 1). One suggested

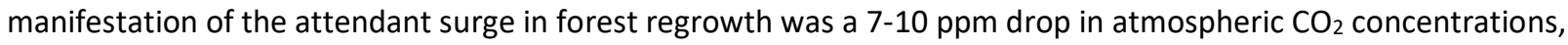
known as the Orbis spike that began c. 1610 and presaged relatively low concentrations until c. 1750 (Fig. 1) (4); a decline that deepened the cooling of The Little Ice Age (1400-1800) (5). Whether the scale of $\mathrm{CO}_{2}$ variation forming the Orbis spike was truly an unusual event has been questioned (6), as was the link to New World depopulation (7). Of all the Americas, the greatest potential carbon response to the Great Dying would have been manifested in the vast, high-biomass, forests of Amazonia $(8,9)$. If the decline in $\mathrm{CO}_{2}$ concentrations was caused by the Great Dying, the depopulation and reforestation must have been rapid and widespread (Fig. 1).

Eyewitness accounts of the state of Amazonian populations in the first 200 years after European contact are sparse, but three accounts stand out, those of Carvajal (11), Acuña (12), and de la Condamine (13). Lured by rumors of gold, the first large Spanish expedition entered lowland Amazonia in 1541 (11). Friar Carvajal, the diarist 
mass disease (11). A similarly positive account of societies and living conditions is provided by Acuña, a Spanish priest who traveled from Quito to Belem in 1639. These two early accounts could have been flavored by a desire to present a land of opportunity to royal courts in Europe (13). In contrast, a French surveyor, de la Condamine, traveled down the Amazon River in 1743, but did not record the same high density of people on the riverbanks, suggesting a partially depopulated landscape (13). Although it seems most probable that any vegetation change associated with the Great Dying took place in Amazonia post-1639 (the date of Acuna's trip), we investigate the possibility that it occurred between 1550 and 1750 concurrent with low CO2 levels $(8,9)$.

Although it is challenging to estimate pre-collapse population size, assumptions of near-synchronous forest regrowth are readily testable using paleoecology. Fossil pollen recovered from lake sediments provide a metric for reconstructing local forest cover and land use (14). If the Great Dying induced the rapid, synchronous forest regrowth, then pollen contained in these fossil pollen records should show the strongest switch of the last 2000 years between open ground and weedy species (as signals of a deforested landscape) to dominance of forest taxa between 1550 and 1750 (Fig. 1). This signal should be particularly strong because lakes were preferred settlement sites for indigenous populations (14). While there is not a 1:1 relationship between pollen percentages and forest cover percentages, records from dense rainforest settings do provide a sensitive index of even small-scale disturbances $(15,16)$. Consistently, within the forested portion of Amazonia, relatively undisturbed forest produces $95-100 \%$ forest pollen (12). Where human disturbance occurs, forest pollen percentages decrease while percentages of open ground and shrubby taxa increase Fossil pollen of weeds, grasses, and crops are usually accompanied by charcoal, which is a direct indicator of anthropogenic forest burning, as natural fires (lightning-induced) occur rarely in Amazonian forests (17). An important taxon in assessing forest disturbance and early stages of recovery is Cecropia, a short-lived, fastgrowing, shade-intolerant pioneer tree that produces abundant and easily identifiable pollen (18). Cecropia occurs naturally as a canopy gap-colonist within forests, and hence is part of our forest pollen component, but it is favored by anthropogenic disturbance and commonly forms a dominant stage in forest succession on abandoned land (19). Abandonment of fields in much of Amazonia would be expected to pass through a Cecropia-rich early successional stage. As the forest matures, Cecropia would be competitively excluded from all but forest gaps, and so a peak of Cecropia pollen in fossil pollen records should be a sensitive marker of the onset of the Great Dying. 
To determine whether reforestation between 1550 and 1750 was associated with changes in global $\mathrm{CO}_{2}$ levels, we assess changes in land use, forest cover, and Cecropia abundances for the last 2000 years based on fossil pollen and charcoal data derived from 39 lake sites across Amazonia (20).

About $80 \%$ of the 39 sites contained signals of forest opening, burning, or cultivation consistent with preEuropean occupation (Fig. 2A, database S1). A spatially and temporally heterogeneous pattern of deforestation, reforestation and, by inference, carbon uptake was evident in the pollen data across the 39 sites (Figs. 2, S1-S2). To assess even minor changes in forest cover, the proportion of sites showing a 5 or $10 \%$ increase or decrease in forest pollen were assessed. Sites exhibiting evidence of deforestation at values > 5\% peaked between 350 and 750, while the proportion of sites showing evidence of reforestation was greatest between 750 and 1550 (Figs. 2c, S1-S2). During the Great Dying period, the number of sites where forest pollen was increasing roughly equalled those where it was falling in abundance (Fig. 2B,C, S1), effectively rejecting the hypothesis of widespread and synchronous reforestation sufficient to cause decreases in atmospheric $\mathrm{CO}_{2}$ levels. Instead of a strong signal of reforestation during or following the Great Dying, our empirical data show that changes in Amazonian land use and forest cover took place several centuries before European arrival (Fig. 2C).

Nine sites out of 39 contain at least 10 pollen samples in the last 1000 years (Fig. S3), and provide centennial-scale temporal resolution (hereafter high-resolution sites). These sites offer the opportunity to investigate trajectories of site disturbance and forest recovery (Fig. 3, database S1). Eight of the nine highresolution sites contain pollen and charcoal evidence of occupation in the pre-Columbian era and provide evidence 20 of changes in forest pollen percentages before, during or after the Great Dying (Fig. 3, database S1). Taken together, the nine sites do not show a pattern of synchronous or substantial reforestation during the Great Dying period (Fig. 3). Instead, these records contain a range of temporal patterns of pre-Columbian occupancy, i.e., longterm sustained use, intermittent use and non-use (17-25). An example of a site showing long-term use is Lake Caranã (Fig. 3), which provides evidence in its fossil pollen and charcoal record of a continuous history of occupation with the frequent use of fire, maize (Zea mays) and squash (Cucurbita spp.) cultivation. Archaeological data at Caranã evidence the formation of Amazonian Dark Earth over the last 2000 years (22). Despite this intensity of use, no significant change in total forest pollen is associated with the Great Dying at Lake Caranã. Lakes 
Rogaguado and Granja were the only pollen records to increase forest pollen abundance by $>10 \%$ between 1550 and 1750 (Fig. 3). Most of the increase at Rogaguado occurred from 1650-1750 CE. While Granja lies in riparian forest today, it is within $1 \mathrm{~km}$ of flooded savanna. A modest increase in precipitation at this site could have caused an increase in forest pollen representation, but that same increase would not affect other locations that were already fully forested. Progressively wetter conditions at Granja over the last 2000 years should have led to increased forest cover, but instead grassland was maintained by human activities until abandonment, ca. 13001400 CE (23). After 1300 CE forest cover increased from $20 \%$ to $>40 \%$ in about a century (Fig. 3 ). Thus, this was not a site where there was a cycle of deforestation, use, and reforestation, as seen at all the other occupied sites; rather human activity suppressed a natural, climatically-induced, trend of rainforest expansion. Among the other sites containing pollen evidence of maize cultivation, fluctuations in forest pollen percentages, indicative of forest clearance and recovery, varied in timing. Sauce (24) and Ayauch (25) had records of long-term forest clearance, whereas Lake Kumpaka (26) was used episodically. Quistococha (27), and the saline Limon (28) provided evidence of human occupation (burning), but no crop pollen. None of the nine sites shows increases in forest pollen during the Great Dying. Lake Pata lies on an inselberg above the Amazon plain, with very thin soils that preclude cultivation (29). A high-resolution pollen analysis of Lake Pata revealed no evidence of human occupancy and forest pollen percentages were $>95 \%$ throughout the last 2000 years (Fig. 3) (29).

When looking at deviations in forest pollen abundance from the 2000-yr mean pollen percentage of each record, only Lake Rogaguado showed significant forest increases during the Great Dying period, particularly from 1650-1750 CE (Fig. 4A). Other lakes showed either no deviation throughout the record or forest percentages that increased relative to mean values between $950-1350$, i.e., 300-600 years prior to the Great Dying event. The largest increase in the mean value of all forest pollen deviations occurred from c. 1250-1350, with no significant increase during the Great Dying period (Fig. 4A, black line). Between 950 and 1350, Cecropia pollen percentages showed the largest increases (ca. 5\%) from mean values, whereas during the Great Dying values were ca. 5\% lower than the long-term mean (Fig. 4B). These data are inconsistent with a postulated peak in post-disturbance succession and rapid carbon uptake following the Great Dying. The negative deviations from the mean Cecropia values for each of the nine lakes correspond with charcoal declines. Such cessation of burning is strongly associated with land abandonment (Fig. 4B,C). The discontinuous charcoal peaks at most sites suggest that forest 
burning was intermittent, and where it occurred, it ceased before the Great Dying (Fig. 4C); a probable indicator of abandonment. The only site to show a decrease in burning between 1650-1750 was Lake Quistococha. Lake Quistococha is located near the city of Iquitos, Peru, in a region where the Jesuits established the Mainas Missions from $1638-1767(30)$.

Our empirical observations are consistent with archaeologically-derived models (2) that suggest stable or falling populations for centuries before European arrival. The mechanisms driving the cultural change or site abandonment from c. 950-1350, however, have yet to be identified. We consider three possibilities that are not mutually exclusive: climate change, societal change, and disease. If climate were mainly responsible, lakes within close proximity to each other would be expected to contain synchronous changes in pollen and charcoal, and regional geographic trends associated with environmental gradients (e.g., Fig. 2A) should be evident in the dataset. They are not. Trends in forest pollen abundance do not seem to have a distinct geographic pattern (Figs. 2B, S1S2), and neighboring sites often show non-synchronous peaks of fire and periods of fire absence (Fig. 4) (31, 32) suggesting that climate change is unlikely to be a complete explanation for the abandonment of sites between 950 and 1250. Our findings do not, however, discount the possibility that climate change could have contributed to a societal response of changing land use, and thus changing forest cover percentages (23). Isotopic data from regional speleothems and lake records both support a trend toward increasing climate variability between 800 and $1200(33,34)$. De Souza et al. (35) suggested that complex, hierarchical, societies relying on specialized food provisions were more susceptible to these climate variations than simpler, more egalitarian societies accessing a breadth of food resources. Many of the sites used in this study have no accompanying archaeological data to determine past human vulnerability to climate change. Nevertheless, even if human populations were resilient, some sites may simply have become too flood- or drought-prone to continue to be desirable, forcing migration to new locations.

The timing of observed reforestation in the lowlands coincides with the relocation of an estimated $25 \%$ of the indigenous population from the Andes into the coastal lowlands between c. 1000 and 1200 (36). This migration is associated with the collapse of the Tiwanaku and Wari cultures, rapid climate change, and evidence of increased warfare evidenced by cranial trauma $(37,38)$. In the Amazon lowlands, increased hostility is inferred from archaeological contexts amid a cultural expansion reflected in the spread of the polychrome tradition of decorated 
pottery (39). To find abandonment of apparently unrelated lowland settings at the same time as that of the highlands raises the possibility of a common cause. Climate change, conflict, and disease could underly both patterns of behavior. Disease outbreaks have yet to be documented in the lowlands, but skeletal remains provide evidence of the Andean expansion of tuberculosis between 1000 and 1300 (40). Trading between lowland and highland communities, which is known for this period (41), could have easily spread disease and created preEuropean pandemics across the region. Thus, the interaction of climate change, social tensions and possibly even the emergence of novel non-European diseases could have caused the observed destabilization of Amazonian populations centuries before the Great Dying period. Populations in some areas of Amazonia may already have been declining when Europeans arrived, a decline that was accelerated by the impacts of disease following European contact. Furthermore, our data suggest that the timing of reforestation was heterogenous with many sites showing an increase in forest cover as much as 600 years before the Great Dying. We find no evidence that human-induced vegetation change in Amazonia influenced global $\mathrm{CO}_{2}$ concentrations either during the early reforestation event documented here or during the Great Dying.

\section{References and Notes:}

1. M. Arroyo-Kalin, Human niche construction and population growth in Pre-Columbian Amazonia. Archaeology International 20, 122-136 (2018).

2. M. Arroyo-Kalin, P. Riris, Did Amazonian pre-Columbian populations reach carrying capacity during the Late Holocene? Philosophical Transactions of the Royal Society B 376, 20190715 (2020).

3. N. D. Cook, Born to die: disease and New World conquest, 1492-1650. (Cambridge University Press, 1998), vol. 1.

4. S. L. Lewis, M. A. Maslin, Defining the Anthropocene. Nature 519, 171 (2015).

5. C. MacFarling Meure et al. , Law Dome CO2, CH4 and N2O ice core records extended to 2000 years BP. Geophysical Research Letters 33, https://doi.org/10.1029/2006GL026152 (2006). (2001). 
7. J. Zalasiewicz et al., Colonization of the Americas, 'Little Ice Age'climate, and bomb-produced carbon: Their role in defining the Anthropocene. The Anthropocene Review 2, 117-127 (2015).

8. A. Koch, C. Brierley, M. M. Maslin, S. L. Lewis, Earth system impacts of the European arrival and Great Dying in the Americas after 1492. Quaternary Science Reviews 207, 13-36 (2019). atmospheric CO2 during European conquest. The Holocene 21, 853-864 (2011).

10. P. A. Martin, A. C. Newton, J. M. Bullock, Carbon pools recover more quickly than plant biodiversity in tropical secondary forests. Proceedings of the Royal Society B: Biological Sciences 280, 20132236 (2013).

11. J. Medina, The discovery of the Amazon according to the account of Friar Caspar de Carvajal and other documents. H. C. Heaton, Ed., (American Geographical Society, New York, 1934).

12. C. Acuña, A relation of the great river of Amazons in South America. Voyages and discoveries in SouthAmerica.: (S. Buckley at the Dolphin over against St. Dunstan's church in Fleet street, London, 1698), vol. https://www.loc.gov/item/02009563/.

13. N. J. H. Smith, The Amazon River Forest: A Natural History of Plants, Animals, and People. (Oxford University Press, New York, 1999).

14. M. B. Bush, M. R. Silman, Amazonian exploitation revisited: Ecological asymmetry and the policy pendulum. Frontiers in Ecology and the Environment 5, 457-465 (2007).

15. B. S. Whitney et al., Constraining pollen-based estimates of forest cover in the Amazon: A simulation approach. The Holocene 29, 262-270 (2019).

16. M. B. Bush, On the interpretation of fossil Poaceae pollen in the humid lowland neotropics. Palaeogeography, Palaeoclimatology, Palaeoecology 177, 5-17 (2002).

17. M. A. Cochrane, in Tropical Fire Ecology, M. A. Cochrane, Ed. (Springer Berlin Heidelberg, 2009), pp. 1-23.

18. J. C. I. Rodgers, S. P. Horn, Modern pollen spectra from Costa Rica. Palaeogeography, Palaeoclimatology, Palaeoecology 124, 53-71 (1996).

19. R. C. Mesquita, K. Ickes, G. Ganade, G. B. Williamson, Alternative successional pathways in the Amazon Basin. Journal of Ecology 89, 528-537 (2001).

20. Materials and methods are available as supplementary materials at the Science website 
21. R. J. Hijmans, S. E. Cameron, J. L. Parra, J. P.G., A. Jarvis, Very high resolution interpolated climate surfaces for global land areas. International Journal of Climatology 25, 1965-1978 (2005).

22. S. Y. Maezumi et al., The legacy of 4,500 years of polyculture agroforestry in the eastern Amazon. Nature plants 4, 540 (2018).

23. J. F. Carson et al., Environmental impact of geometric earthwork construction in pre-Columbian Amazonia. Proceedings of the National Academy of Sciences 111, 10497-10502 (2014).

24. M. B. Bush, A. Correa-Metrio, R. Woesik, C. R. Shadik, C. N. McMichael, Human disturbance amplifies Amazonian El Niño-Southern Oscillation signal. Global Change Biology 23, 3181-3192 (2017).

25. C. Åkesson, Humans, vegetation and drought in Late-Holocene Amazonia. Unpublished Ph.D. thesis. Florida Institute of Technology, Melbourne, FI, USA (2019).

26. C. Åkesson et al., Long-term ecological legacies in western Amazonia. Journal of Ecology 1, $432-446$ (2021).

27. T. J. Kelly et al., Continuous human presence without extensive reductions in forest cover over the past 2500 years in an aseasonal Amazonian rainforest. Journal of Quaternary Science 33, 369-379 (2018).

28. G. M. Cárdenes-Sandí, Reconstrucción del escenario ambiental durante los últimos la cuenca del Lago Limón, 2200 años de la zona de Amazonía Peruana. Unpublished M.S. thesis, Universidad de Costa Rica.

29. M. N. Nascimento et al., Vegetation response to climatic changes in western Amazonia over the last 7,600 years. Journal of Biogeography 46, 2389-2406 (2019).

30. M.-E. Reeve, Regional interaction in the Western Amazon: The early colonial encounter and the Jesuit years: 1538-1767. Ethnohistory, 106-138 (1993).

31. M. B. Bush et al., Holocene fire and occupation in Amazonia: Records from two lake districts. Philosophical Transactions of the Royal Society of London. Ser. B. 362, 209-218 (2007).

32. C. N. H. McMichael et al., Sparse pre-Columbian human habitation in western Amazonia. Science 336, 1429-1431 (2012).

33. B. W. Bird et al., A 2,300-year-long annually resolved record of the South American summer monsoon from the Peruvian Andes. Proceedings of the National Academy of Sciences 108, 8583-8588 (2011). 
34. X. Wang et al., Hydroclimate changes across the Amazon lowlands over the past 45,000 years. Nature 541, 204-207 (2017).

35. G. J. de Souza et al., Climate change and cultural resilience in late pre-Columbian Amazonia. Nature Ecology \& Evolution 3, 1007-1017 (2019).

36. L. Fehren-Schmitz et al., Climate change underlies global demographic, genetic, and cultural transitions in pre-Columbian southern Peru. Proceedings of the National Academy of Sciences 111, 9443-9448 (2014).

37. E. Arkush, T. A. Tung, Patterns of war in the Andes from the Archaic to the Late Horizon: insights from settlement patterns and cranial trauma. Journal of Archaeological Research 21, 307-369 (2013).

38. C. R. Ortloff, A. L. Kolata, Climate and Collapse: Agro-Ecological Perspectives on the Decline of the Tiwanaku State. Journal of Archaeological Science 20, 195 (1993).

39. C. de. P. Moraes, E. G. Neves, O Ano 1000: Adensamento Populacional, Interação e Conflito na Amazônia Central. Amazônica: Revista de Antropologia 4, 122- 148 (2012).

40. E. A. Nelson, J. E. Buikstra, A. Herbig, T. A. Tung, K. I. Bos, Advances in the molecular detection of tuberculosis in pre-contact Andean South America. International Journal of Paleopathology, (2020).

41. W. B. Church, A. Von Hagen, in The Handbook of South American Archaeology. (Springer, 2008), pp. 903926.

42. H. Eva et al., "A proposal for defining the geographical boundaries of Amazonia," (EU 218, Luxembourg, 2005).

43. R. C. Mesquita, K. Ickes, G. Ganade, G. B. Williamson, Alternative successional pathways in the Amazon Basin. Journal of Ecology 89, 528-537 (2001).

44. M. J. Power et al., Changes in fire regimes since the Last Glacial Maximum: an assessment based on a global synthesis and analysis of charcoal data. Climate dynamics 30, 887-907 (2008).

45. C. N. H. McMichael, B. M. Heijink, M. B. Bush, W. D. Gosling, On the scaling and standardization of charcoal data in paleofire reconstructions. Frontiers in Biogeography doi:10.21425/F5FBG49431, (2021).

46. P. A. Colinvaux, M. Frost, I. Frost, K.-b. Liu, M. Steinitz-Kannan, Three pollen diagrams of forest disturbance in the western Amazon basin. Review of Palaeobotany and Palynology, 73-81 (1988). 
47. I. Frost, A Holocene sedimentary record from Añangucocha in the Ecuadorian Amazon. Ecology 69, 66-73 (1988).

48. C. Weng, M. B. Bush, J. S. Athens, Holocene climate change and hydrarch succession in lowland Amazonian Ecuador. Review of Palaeobotany and Palynology 120, 73-90 (2002). basin in central Colombian Amazon. Palaeogeography, Palaeoclimatology, Palaeoecology, 145, $193-213$ (1999).

50. K. H. Roucoux et al., Vegetation development in an Amazonian peatland. Palaeogeography, Palaeoclimatology, Palaeoecology 374, 242-255 (2013).

51. T. J. Kelly et al., The vegetation history of an Amazonian domed peatland. Palaeogeography, Palaeoclimatology, Palaeoecology 468, 129-141 (2017).

52. D. H. Urrego et al., Holocene fires, forest stability and human occupation in south-western Amazonia. Journal of Biogeography 40, 521-533 (2013).

53. M. L. Absy, A palynological study of Holocene sediments in the Amazon basin. Unpublished Ph.D. Dissertation, University of Amsterdam, Amsterdam (1979).

54. H. Behling, M. L. da Costa, Holocene environmental changes from the Rio Curuá record in the Caxiuanã region, eastern Amazon Basin. Quaternary Research 53, 369-377 (2000).

55. H. Behling, Late Quaternary environmental changes in the Lagoa da Curuça region (eastern Amazonia, Brazil) and evidence of Podocarpus in the Amazon lowland. Vegetation History and Archaeobotany 10, 175-183 (2001).

56. H. Behling, G. Keim, G. Irion, W. Junk, J. N. De Mello, Holocene environmental changes in the central Amazon Basin inferred from Lago Calado (Brazil). Palaeogeography, Palaeoclimatology, Palaeoecology 173, 87-101 (2001).

57. N. de. P. Sá, M. L. Absy, E. A. A. Soares, Late Holocene paleoenvironments of the floodplain of the Solimões River, Central Amazonia, based on the palynological record of Lake Cabaliana. Acta Botanica Brasilica 30, 473-485 (2016). 
58. M. B. Bush, M. R. Silman, C. M. C. S. Listopad, A regional study of Holocene climate change and human occupation in Peruvian Amazonia. Journal of Biogeography 34, 1342-1356 (2007).

59. M. B. de Toledo, M. B. Bush, A mid-Holocene environmental change in Amazonian savannahs. Journal of Biogeography 34, 1313-1326 (2007).

60. S. O. Brugger et al., Long-term man-environment interactions in the Bolivian Amazon: 8000 years of vegetation dynamics. Quaternary Science Reviews 132, 114-128 (2016).

61. B. Hermanowski, M. L. da Costa, H. Behling, Environmental changes in southeastern Amazonia during the last 25,000 yr revealed from a paleoecological record. Quaternary Research 77, 138-148 (2012).

62. F. E. Mayle, R. Burbridge, T. J. Killeen, Millennial-scale dynamics of southern Amazonian rain forests. Science 290, 2291-2294 (2000).

63. R. E. Burbridge, F. E. Mayle, T. J. Killeen, 50,000 year vegetation and climate history of Noel Kempff Mercado National Park, Bolivian Amazon. Quaternary Research 61, 215-230 (2004).

64. M. B. De Toledo, Holocene vegetation and climate history of savanna-forest ecotones in northeastern Amazonia. unpublished Ph.D. thesis. Florida Institute of Technology, Melbourne (2004). Quaternary Science Reviews 141, 52-64 (2016).

Acknowledgments: The authors wish to acknowledge the governments and people of Brazil, Colombia, Ecuador, Peru, and Bolivia who facilitated this work. Funding: Ecuadorian work was conducted under Ecuadorian Collection Permit 08-2017-IC. MBB would like to acknowledge funding from the National Science Foundation (grant nos. EAR1338694 and BCS0926973) and the National Aeronautics and Space Administration (grant no. NNX14AD31G). CNHM and MNN would like to acknowledge funding from the European Research Council (ERC 2019 StG 853394). MNN also acknowledges a Florida Institute of Technology postdoctoral Award. TK acknowledges a NERC funded PhD studentship; Author contributions: MBB and CNHM conceived the study, and were engaged in all aspects of data gathering, analysis, figure presentation, and writing. Those contributing data: MNN, CMÅ, HB, GC, TK, SNH, AC-M, 
SYM, FEM. Those contributing to figures and analyses: MNN, SYM. Those also contributing to writing: WC, FEM, TK.

Competing interests: Authors declare no competing interests.

Data and materials availability: All data are available in the main text or the supplementary materials.

$5 \quad$ Full records for some sites are available from NEOTOMAdb.org (Database S1).

\section{List of supplementary materials:}

\section{Supplementary materials}

Materials and Methods

Figs. S1-S3

10

References 35-60

Database S1 (separate file) 


\section{Figure legends}

Fig. 1: How reforestation could relate to atmospheric carbon concentrations. Atmospheric $\mathrm{CO}_{2}$ concentrations (blue line) (5) showing the $7-10 \mathrm{ppm}$ decline at 1610 are attributed to the Great Dying. Expected carbon uptake patterns associated with occupation, abandonment, and forest recovery are shown for 1550-1750, following the observation that the most intense sequestration takes place in the first century of succession (10).

Fig. 2: Sites used in the analysis. A) Distribution of 39 lake sediment records shown in the context of precipitation of the driest quarter (i.e. the 3 consecutive months per year with the lowest precipitation values) (21) with larger symbols representing the high-resolution sites (Figs. 3, 4A-C). Color-coding indicates whether evidence of past human occupation was present in the record. B) Forest change during the Great Dying period. Color coding indicates whether pollen percentages at each site had increased (green) or decreased (purple) at least $5 \%$ during the Great Dying period, compared with samples in the previous time window. C) The proportion of sites that were losing or gaining either $5 \%$ or $10 \%$ of forest pollen (compared with samples in the previous time window) over the last 2000 years, using 200-year time bins (-50 to 1950). Dark gray vertical bar indicates the Great Dying period.

Fig 3: Variability in pollen percentages of forest taxa over the last 2000 years documented at the nine high-resolution lake sites. Sites are color-coded by the percentage of samples in the record containing the presence of maize pollen, a direct indicator of cultivation (External database S4-12). Vertical grey bar indicates the Great Dying period (1550-1750 CE).

Fig. 4: Changes in forest pollen abundance and forest burning. Percentage differences from the site mean (0-2000 CE) for A) forest pollen and B) Cecropia, for the nine highresolution sites. Data are interpolated to 100-year time slices. C) The Charcoal Index values represent the charcoal abundance data for each lake, scaled and standardized to values between 0 (absence of fire) and 100 (maximum charcoal abundance given that all samples contain charcoal). The standardization allows comparisons across sites 
(16). Mean values (black line) for panels $A-C$ indicate the average value across all sites for each 100-year time window.

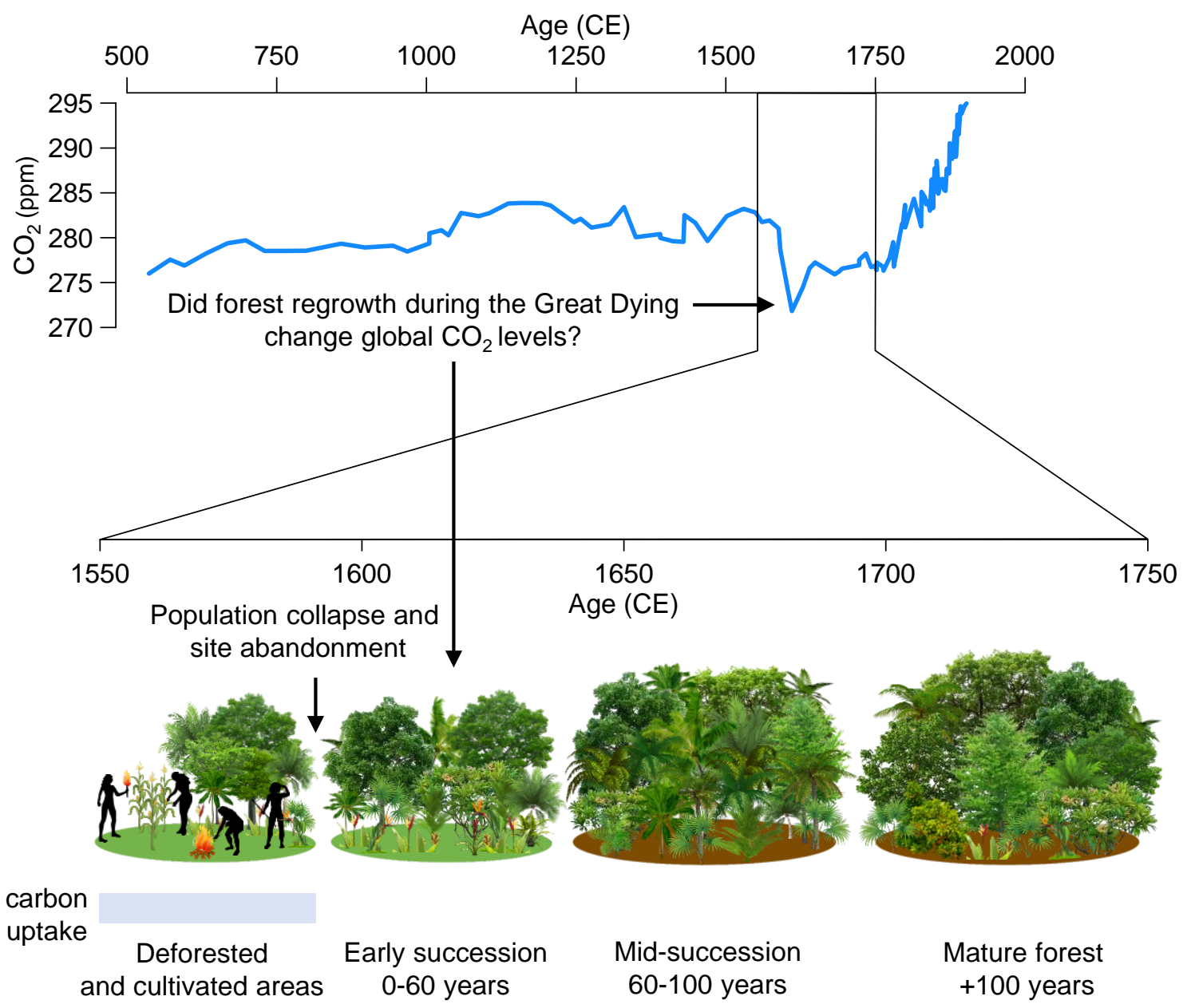

Fig. 1 

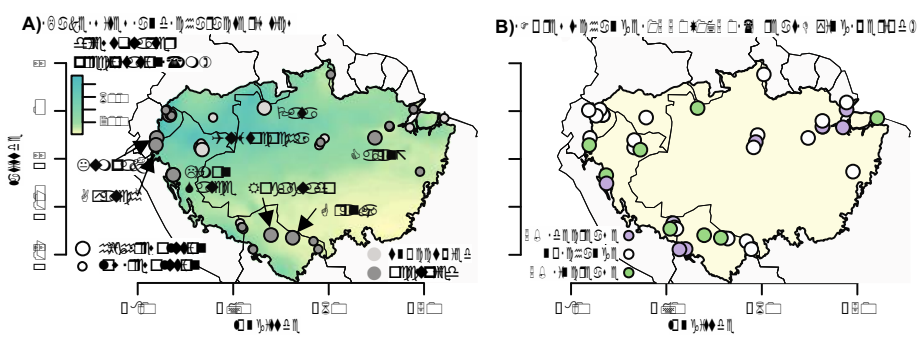

C).

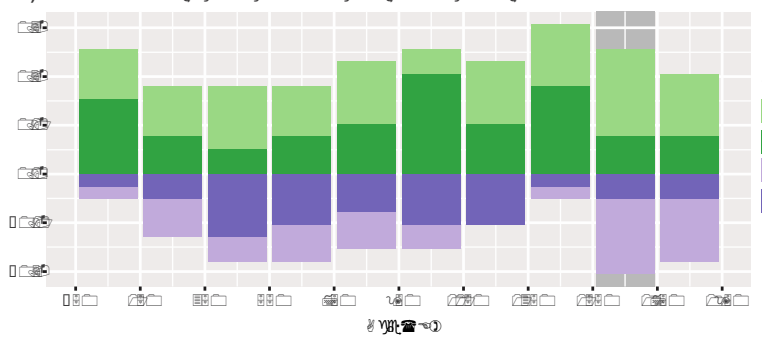

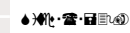

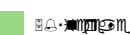

(7) - masm

ब0.

Fig. 2 


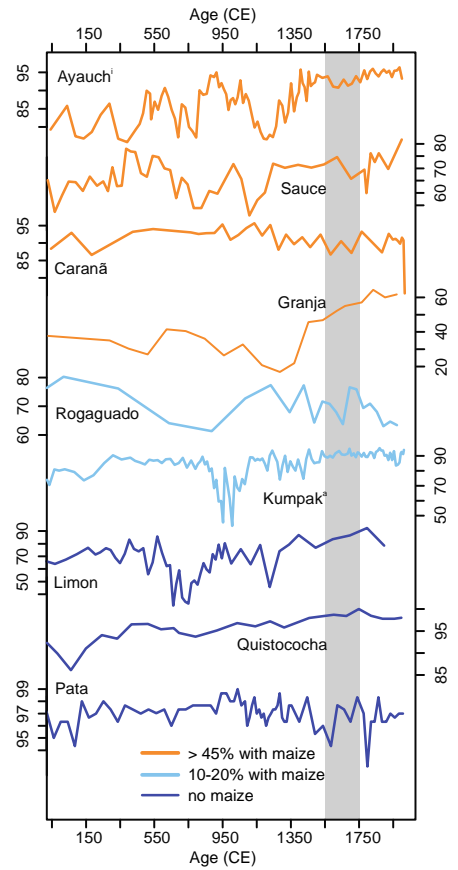

Fig. 3 

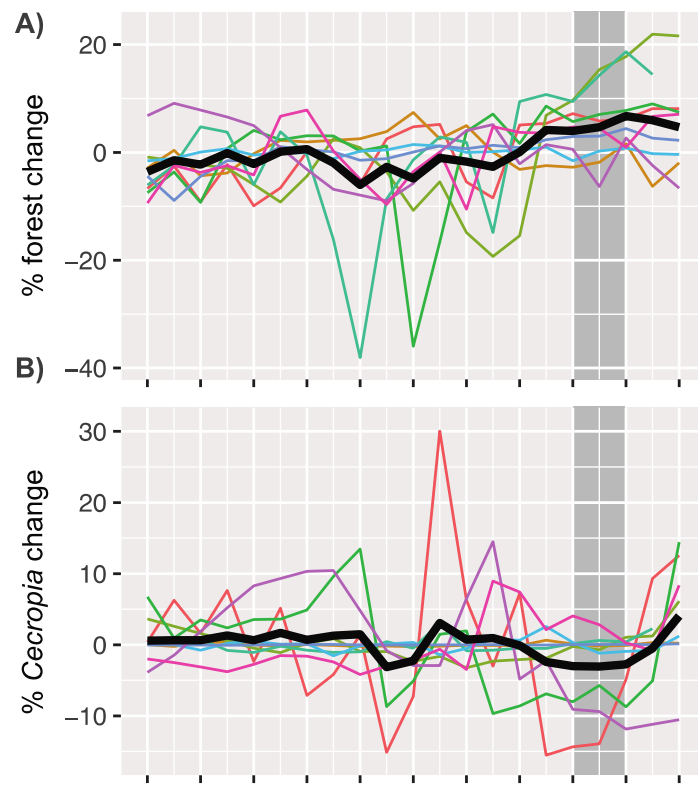

C)

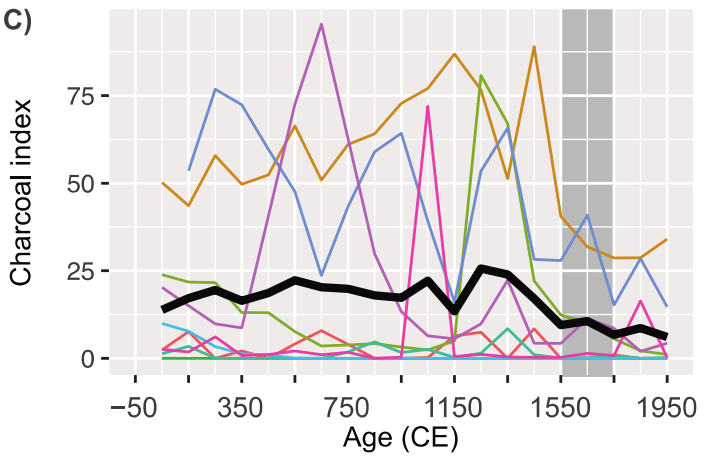

Sites $(N=9)$

- Ayauch

- Caranã

- Granja

- Kumpak

- Limon

- Pata

- Quistococha

- Rogaguado

- Sauce

mean

- $\%$ change in pollen

mean

- \% change in

charcoal

Fig. 4 


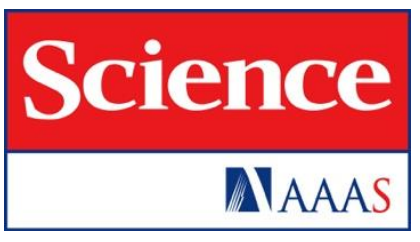

\section{Supplementary Materials for}

\section{Widespread reforestation before European influence on Amazonia}

M.B. Bush ${ }^{1 *}$, M.N. Nascimento ${ }^{1,3}$, C.M. Åkesson ${ }^{1} \dagger$, G.M. Cárdenes-Sandî, S.Y. Maezumi ${ }^{3}$, H. Behling ${ }^{4}$, A. CorreaMetrio $^{5}$, W. Church ${ }^{6}$, S.N. Huisman ${ }^{3}$, T. Kelly ${ }^{7}$, F.E. Mayle ${ }^{8}$, C.N.H. McMichael ${ }^{3 *}$

correspondence to: $\underline{\text { mbush@fit.edu }} \underline{\text { c.n.h.mcmichael@uva.nl }}$

This PDF file includes:

Materials and Methods

Supplementary Text

Figs. S1 to S3

Captions for databases S1

Other Supplementary Materials for this manuscript includes the following:

Database S1:

Table 1: Metadata for all sites used in the analysis

Table 2: Percentage of change in forest pollen in comparison with previous time slice, highlighting increases or decreases $\geq 5 \%$.

Table 3: Percentage of change in forest pollen in comparison with previous time slice, highlighting increases or decreases $\geq 10 \%$.

Tables 4,6,8,10,12,14,16,18,20: Total pollen abundance of forest, Cecropia, Mauritia, and maize presence against age (cal yr BP and CE) for the 9 high-resolution study sites used in this study.

Tables 5,7,9,11,13,15,17,19,21. Charcoal abundances against age (cal yr BP and CE) for the 9 high-

resolution study sites used in this study. 


\section{Materials and Methods}

$\underline{\text { Analysis }} \underline{\text { of lake sediments }}$

We compiled fossil pollen and charcoal data from 39 lake-sediment records (database S1) in Amazonia sensu stricto (42). We did not include pollen or charcoal reconstructions from peatland or palm swamp settings. To be included, all sites had to have a minimum of six fossil pollen samples within the last 2000 years and appear to be continuous records. The categorization of 'occupied sites' for the 39 lake sediments was based on the presence of cultigen pollen (predominantly Zea mays), increases in the pollen of grasses and weeds, or the presence of charcoal.

For each site $(\mathrm{N}=39)$, we calculated the total forest percentage of all tree and shrub taxa contained in the pollen record (including Cecropia) (database S1). Cecropia pollen percentages are also shown separately, as this tree is an indicator of site abandonment and early successional forest regrowth (43). Raw pollen counts were not available for all lakes, but for those reported, pollen counts are generally > 300 grains per sample (database S1). At Lake Caranã, Mauritia pollen was so abundant that it represented $>84 \%$ of the total pollen sum (22). As Mauritia is an obligate wetland palm, this local pollen representation could mask changes in forest cover in the adjacent uplands. Consequently, Mauritia was excluded from the pollen sum for Lake Caranã, and forest pollen percentages were recalculated. Prior work in modern Amazonian settings has shown that forest disturbance by humans $(15,16)$ is revealed by a reduction in the proportion of forest pollen by $5-10 \%$. Based on prior assays of the sensitivity of forest pollen representation to human disturbance we tabulated the proportion of sites that in contiguous samples lost or gained at least $5 \%$ or $10 \%$ of total forest pollen for each 200 -year time window from -50 to 1950 (databases S1, Fig. S1).

Nine of the 39 lake sedimentary records (referred to as high-resolution sites) contain at least two dates over the last 2000 years, and over 10 pollen and charcoal samples in the last 1000 years (database S1, Fig. S3). The high-resolution sites are used to provide temporally detailed changes in the amount of forest pollen abundances before, during, and after the Great Dying period (1550-1750). We show the changes in forest pollen percentages for all the high-resolution sites, and also the deviation from the mean forest percentage for each site in 100-year time bins. We also present the mean of those deviations across sites for the last 2000 years. We show the same for Cecropia pollen.

The charcoal samples reported here were collected by many investigators, and thus sample preparation and measurement methods did not follow a standardized protocol (Database $\mathrm{S} 1$, Table 1). Without such a protocol a standardization method is necessary to account for differences in laboratory procedure, catchment size, and sediment properties when comparing charcoal amounts across sites (44). We performed proportional relative scaling to standardize the charcoal abundance data from each lake record (45), and report it as the Charcoal Index Value.

$$
\text { Charcoal Index Value }=\left(\frac{c_{i}}{c_{\max }} * 100\right) * f / N
$$

This approach scales each measurement $\left(\mathrm{c}_{\mathrm{i}}\right)$ within each lake sediment record to a value ranging between 0 and 100, where 0 is the absence of charcoal and 100 is the maximum abundance measurement for that record $\left(c_{\max }\right)$. The scaled measurements are then multiplied by the proportion of samples within the record containing charcoal $(\mathrm{f} / \mathrm{N})$. Proportional relative scaling is particularly robust in assessing fire in systems where fire is infrequent or rare, because 
0 is used as the true absence value, and samples containing small or infrequent amounts of charcoal are down-weighted (45). The scaled data are reported as the Charcoal Index value. We show the Charcoal Index values for each site, and the mean of the Charcoal Index values across all sites $(\mathrm{N}=9)$ for 100 -year time windows for the last 2000 years.

5

\section{Supplementary Text}

$\underline{\text { References (see main text for full list of references) }}$ 


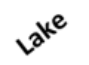

1 - Agrio

2 - Anangucocha

3 - Ayauch

4 - Kumpak

5 - Limon

6 - Limoncocha

7 - Maxus-1

8 - Maxus-4

9 - Pantano de Monica

10 - Pata

11 - Quistococha Lake

12 - Quistococha Peat

13 - San Jorge

14 - Santa Cecilia

15 - Chalalan

16 - Caju

17 - Curua

18 - Santa Rosa

19 - Curuca

20 - Carana

21 - Calado

22 - Cabaliana

23 - Werth

24 - Gentry

25 - Parker

26 - Vargas

27 - Marcio

28 - Tapera

29 - Rogaguado

30 - Geral

31 - Santa Maria

32 - Saracuri

33 - Granja

34 - Oricore

35 - Carajas

36 - Bella Vista

37 - Chaplin

38 - Jacare

39 - Sauce
Age (CE)

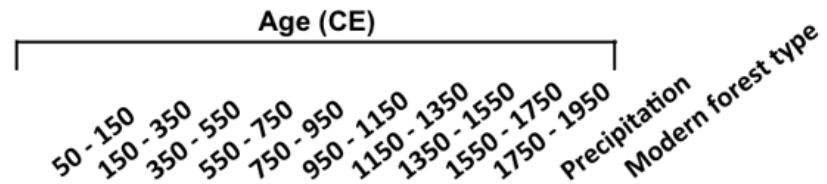

0000000008

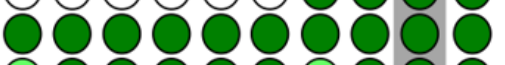

0000000000

0000000000

0000000000

0000000000

0000000000

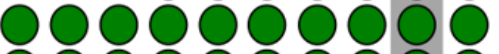

0000000000

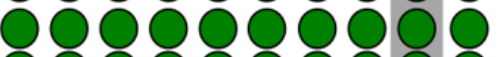

0000000000

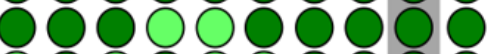

0000000000

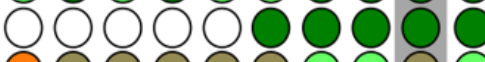

0000000000

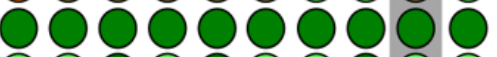

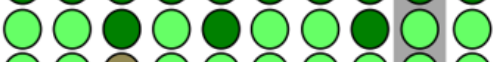

80

00

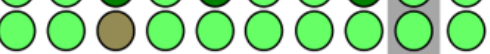

0000000000

000000000800

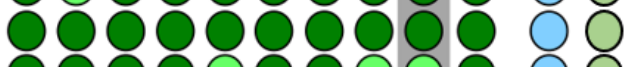

000

000000000000

0000000000 ด

000000000000

000000000000

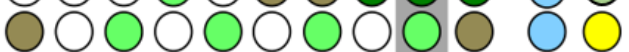

000000000000

000000000000

000000000000

๑०००००००००००

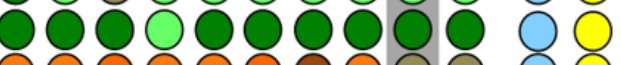

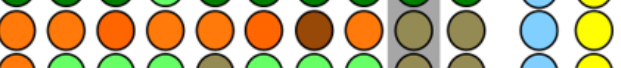

80008000800

000000000000

000000000000

000000000000

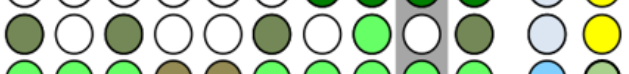

\begin{tabular}{|l|} 
Legend \\
Forest pollen (\%) \\
80 - 100 \\
60 to 80 \\
40 to 60 \\
20 to 40 \\
Up to 20 \\
No data \\
Precipitation (mm yr ${ }^{-1}$ ) \\
$>3000$ \\
2000 to 3000 \\
1000 to 2000 \\
Main forest type \\
Moist evergreen \\
Savanna forest transition
\end{tabular}

Fig. S1.

Summary of the change in forest per 200 years over the last 2000 years in the 39 study sites. The gray bar identifies the period of arrival of Europeans. See database S1, for references and site characteristics. 



Fig. S2

Spatial and temporal pattern of sites showing increases or decreases in forest pollen of $>5 \%$, using 200-year windows. Light yellow outline shows boundaries of Amazonia sensu stricto (38). 


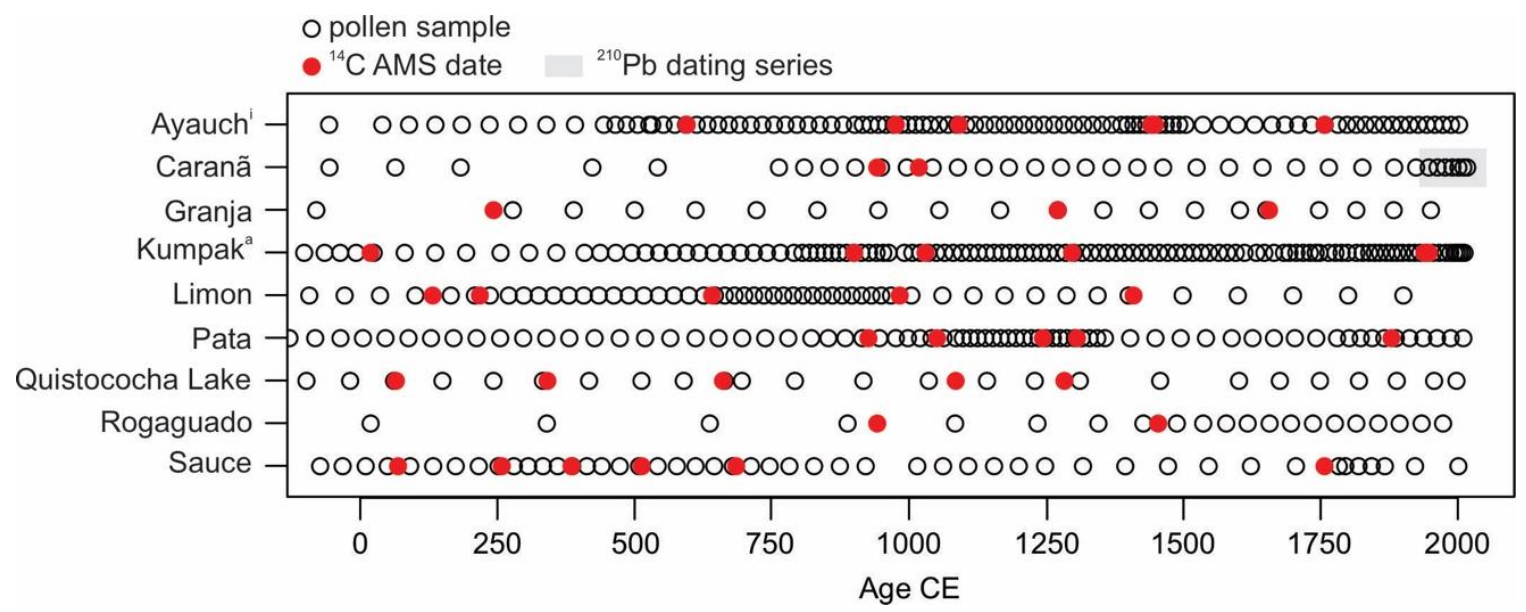

\section{Fig. S3}

Sampling resolution of the nine high-resolution sites used in the analyses. See database S1 for further site characteristics and data. 


\section{Additional Data table S1 (separate file)}

Database S1 contains the data on the site characteristics, pollen, and charcoal data used in this analysis. Table 1 contains all of the metadata on the sites and references to original publications. Table 2-3 contains the percentages in forest pollen change compared with the previous samples (for 5\% and 10\%) thresholds. The remaining tables contain the charcoal and pollen data for the nine high-resolution sites used in the analysis. 